УдК 339.9

P.O. Мaдяp,

к. е.н., дочент, дочент кафедри економічної теорії,

АВНЗ "Ужгородський начіональний університет", м. Ужгород

ORCID ID: 0000-0001-6148-9223

B. P. Гадьмаші,

здобувач освітнього ступеня "магістр", спечіальність "Аогістика",

АВНЗ "Ужгородсъкий начіональний університет", м. Ужгород

ORCID ID: 0000-0002-2824-9751

C. M. Аалекорей,

здобувач освітнього ступеня "магістр" , спечіальність " Аогістика", АВНЗ "Ужгородсъкий начіональний університет", м. Ужгород

ORCID ID: 0000-0001-8264-2012

DOI: $10.32702 / 2306-6814.2021 .1 .66$

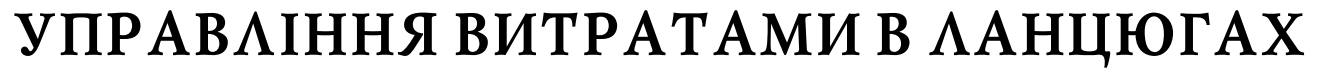 ПОСТАЧАННЯ ЯК ІНСТРУМЕНТ АОСЯГНЕННЯ КОНКУРЕНТНИХ ПЕРЕВАГ БІЗНЕСУ В ГАОБА ЬЬНОМУ ЕКОНОМІЧНОМУ ПРОСТОРI
}

\author{
R. Madyar, \\ $\mathrm{PhD}$ in Economics, Associate Professor, Associate Professor of the Department \\ of Economic theory, Uzhhorod National State University, Uzhhorod \\ V. Hadmashi, \\ Master's student, specialty "Logistics", Uzhhorod National State University, Uzhhorod \\ S. Dalekorei, \\ Master's student, specialty "Logistics", Uzhhorod National State University, Uzhhorod
}

\section{MANAGING SUPPLY CHAIN COSTS AS A TOOL TO ACHIEVE COMPETITIVE BUSINESS BENEFITS IN THE GLOBAL ECONOMIC SPACE}

У статті здійснено аналіз ланцюгів постачання та сформовано пропозиції щодо управління ними 3 метою підвищення ефективності функціонування логістичних систем підприємства. Теоретичний аналіз оптимізації ланцюгів постачання передбачає комплексність цього процесу та має маркетинговий, логістичний, інформаційно-комунікаційний та інші виміри. Управління ланцюгами постачання охоплюють стратегічні, тактичні та оперативні рівні діяльності організації. Констатовано, що функціонування логістичної системи в умовах динамічного зовнішнього середовища пов'язане із виникненням багатьох проблемних ситуацій. Досліджено, що з великої кількості показників, найдоцільніше при визначенні ефективності управління ланцюгом постачання, використовувати два - рівень надійності роботи ланцюга та рівень ризику щодо своєчасності поставки замовникам продукції. Доведено, що логістичний підхід до управління транспортно-логістичними витратами останнім часом суттєво змінився, більшою мірою стали використовуватись інноваційні підходи, які об'єднали сферу виробництва та постачання продукції. Використання нових форм партнерської співпраці та новітніх інформаційних технологій сприяє розвитку нових господарських стосунків між виробниками, постачальниками та споживачами продукції, а також підвищує ефективність спільного управління процесами постачання.

Зазначено, що ефективна організація і управління ланцюгом постачань є вельми важливим напрямом підвищення конкурентоспроможності підприємств України в умовах глобалізації та сприяє економічному розвитку національної економіки загалом. Тому подальшим перспективним розвитком логістики є ефективне управління ланцюгами постачання, щоє свідченням зростаючого розуміння компаніями важливості координації всіх функцій і бізнес-процесів, оскільки виробництво якісних ідоступних за ціною товарів без впровадження на підприємствах системи реєстрації, облікута контролю логістичних витрат, є неможливим. Важливим є розуміння того, що через інтеграцію, кооперацію та партнерство у всіх ланках регіональних логістичних систем - виробничих та інфраструктурних підприємств, органів державної влади, можна добитися отримання синергетичних ефектів у ланцюгах постачання. 
The author of the article analyzed supply chains and offered to manage them in order to improve the efficiency of the logistics systems of companies. The aurhor mentions that the theoretical analysis of supply chain optimization implies complexity of this process in realms of marketing, logistics, information, communication and other dimensions. It is said that supply chain management covers all activities of the organization: from strategic levels to tactical and operational ones. It is stated that the functioning of the logistics system in the dynamic external environment is associated with the emergence of problematic situations, for example, due to the discrepancy to the declared indicators of reliability and quality of deliveries of finished products, the emergence of commercial and technological loss of goods, etc.. The author proved that the effectiveness of supply chain management is assessed with the help of many indicators, but, according to the experience of European and American logistics companies, it is sufficient to use two indicators - the level of reliability of the chain and the level of risk regarding the timeliness of delivery of products to the customer. Adding to this, the logistics approach to managing transport and logistics costs has changed drastically over the past decade. Moreover, logistics and the concept of supply chain management (SCM) have become highly developed innovation areas of the industry including the field of production and delivery of products. This became possible due to the emergence and development of new economic between manufacturers, suppliers and consumers of products owing to joint management of resource supply processes on the basis of the use of forms of partnership cooperation and the latest information technologies.

The author also mentions that the further perspective development of logistics is the monitoring and management of supply chains that lead to the growing understanding of companies the importance of coordinating all functions and business processes. A very important direction in increasing the competitiveness of Ukrainian enterprises, in terms of globalization, is the production of high-quality and affordable goods. Achieving this goal without implementation of the system of registration, accounting and monitoring of logistics costs at enterprises is impossible. It is important to pay more attention to obtaining synergistic effects in supply chains through integration, cooperation and partnership of all levels of regional logistics systems - production and infrastructure enterprises, organizations and authorities. The author concludes that the established schemes of management of logistics systems provide wide opportunities for usage in logistics practice.

Ключовіслова: логістика, упраВління Витратами, оптимізація ланцюгівпостачання, бізнес, логістична система, підприємство, глобальна економіка.

Key words: logistics, costmanagement, supply chain optimization, business, logistics system, enterprise, global economy.

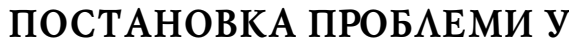

\section{ЗАГААЬНОМУ ВИГАЯАІ ТА ЇÏ ЗВ'ЯЗОК I3 ВАЖАИВИМИ НАУКОВИМИ ЧИ \\ ПРАКТИЧНИМИ ЗАВААННЯМИ}

Через системну інтеграцію та співпрацю, при усуненні географрічних, галузевих і внутрішньокорпоративних перешкод, глобальна економіка отримує додаткові вигоди. Для отримання конкурентних переваг корпорації та компанії об'єднують партнерські зусилля, викликані потребою в зниженні невизначеностей та ризиків, у ході спільної взаємодії в ланцюгах постачання. Цей фрактор відіграє стратегічну роль у функціонуванні систем менеджменту безпеки ланцюгів поставок іє превалюючим [1, с. 352].

Забезпечити конкурентоспроможність українських товарів на європейському ринку та прискорити євроінтеграційні процеси, що відбуваються в національній економіці, можна частково через вирішення організаційноекономічних проблем формування ефективних ланцюгів постачання. До недоотримання прибутку, незадоволення потреб клієнтів та недосягнення мети фрункціонування підприємства призводить недосконала операційна діяльність самого підприємства, в тому числі і логістична. А тому в сучасних нестабільних умовах, питання уникнення цієї проблеми та боротьби з нею, якщо вона вже існує, є важливими і актуальними для будь-якого підприємства. В цій статті здійснюється аналіз ланцюгів постачання та надаються пропозиції щодо управління ними з метою досягнення конкурентних переваг підприємств і підвищення ефективності функціонування логістичних систем.

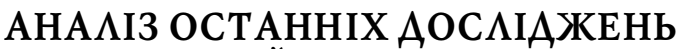 І ПУБАІКАЦІЙ}

Дослідники виділяють шість основних напрямів, на яких зосереджується увага управління ланцюгами поставок: виробництво, місце розташування, постачання, транспортування, запаси, інфрормація. Безліч науковців як закордонних так і вітчизняних у своїх дослідженнях схилялися до того, що компанія може досягти конкурентних переваг та стати більш прибутковою за допомогою реорганізації ланцюгів постачання та вдосконалення бізнес-процесів в ланцюгах постачання.

Система управління витратами в ланцюгу постачання досліджувалась такими вченими: М.І. Долішній, М.П. Денисенко, М.А. Козоріз, Т.О. Колодізєва, Є.В. Крикавський, П.Р. Левковець, О.М. Сумець, О.М. Тридід, Н.І. Чухрай. Проблеми оптимізації та прогнозування логістичних процесів добре висвітлили такі автори: А.М. Гаджинський, А.А. Грешилов, В.Р. Кігель. М.Р. Ліндерс, Х.Е. Фірон, Д.Е. Ханк. Особливої актуальності набувають дослідження проблем управління витратами у ланцюгах постачання в умовах європейської інтеграції України та виходу на світові ринки, що передбачає необхідність їх моніторингу, аналізу та оцінювання з метою підвищення ефективності фрункціонування логістичних ланцюгів.

\section{META CTATTI}

Метою статті $є$ розкриття сутності та особливостей системи управління витратами в ланцюгах постачання 3 метою підвищення конкурентоспроможності бізнесу в глобальному економічному просторі. 
ВИК ААА ОСНОВНОГО МАТЕРІААУ АОС АIАЖЕНHЯ

Ланцюг постачання - це лінійно-впорядкована глобальна мережа (виробників, дистриб'юторів, складів загального користування та ін.), яка керуючи потоками інформації, матеріальних цінностей та грошових коштів, перетворює вихідну сировину на продукти і послуги, які необхідні кінцевому споживачеві. В XXI ст. на зміну технологічній та маркетинговій парадигмам прийшла інтегральна парадигма логістики, яка відповідає інноваційним та мережевим виробничо-логістичним концепціям формування ланцюгів поставок національними підприємствами, а також глобальним викликам світової економіки. Найсучасніша концепція управління підприємствами передбачає пряму залежність ефективності логістичної діяльності національних підприємств від формування ними оптимальних ланцюгів поставок (ЛП) і впровадження досконалих принципів управління ланцюгами поставок (УЛП, SCM Supply Chain Management) - [2, с. 3]. Під час побудови глобальних ланцюгів постачання всі логістичні рішення зводяться до таких параметрів [3, с. 48-54]: зміна потреб споживачів і поява нових очікувань, мережева економіка, глобалізація та складність логістичних процесів, нестабільність середовища, сталість розвитку системи, зростання ризиків, відсутність надійної інфрраструктури, зростання урядових обмежень і бар'єрів. Ці світові логістичні акценти відображені в глобальних програмах Світового Економічного Форуму (The World Economic Forum), а також у працях відомих економістів Світової Організації Торгівлі (The World Trade Organization) і Глобального інституту (Fung Global Institute).

Ефективне управління ланцюгами поставок (УЛП) передбачає партнерську інтеграцію постачальників, виробників, дистриб'юторів і безпосередніх точок продажів товарної продукції та сприяє раціональному розподілу продукції, що виробляється. Тобто повинна досягатися мета мінімізації логістичних витрат у межах ланцюга, зі спрямуванням продукції в потрібне місце, в необхідній кількості, в зазначений час, з гарантією високого рівня надання послуг.

За ефективного управління ланцюгами поставок повинні враховуватись всі можливі фактори та умови, що можуть впливати на собівартість товару, а також обов'язково мають враховуватися всі вимоги споживачів. Вартість у межах ланцюга постачання (постачальники $\rightarrow$ виробники $\rightarrow$ споживачі) повинна бути якомога нижчою, а ефрективність фрункціонування ланцюга по всій його довжині і ширині - якомога вищою. Забезпеченість цього процесу можна вважати головною метою управління ланцюгом постачання. Основними завданнями управління ЛП слід визнати:

- підвищення рентабельності організації з акцентуванням уваги на підвищенні доходів, використанні реклами, зменшенні собівартості;

- координація всіх логістичних видів діяльності в межах ланцюга поставок та створення для клієнта якісного товар, а також підвищення прибутковості для кожної ланки ЛП;

- швидше і ефрективне покращення організації надання послуг клієнтам, з врахуванням вимог клієнтів і координації зусиль всіх ланок ЛП, а також підвищити фрінансових показників.
Ефективне управління ланцюгами постачання передбачають всі види організаційної діяльності оперативного, тактичного та стратегічного рівнів. Всі логістичні рішення, що стосуються кількості, місцезнаходження іємності виробничих приміщень та складів, потоку сировини і готової продукції через логістичний ланцюг, носять характер довгострокового впливу на підприємство, приймаються на стратегічному рівні. Рішення щодо планування на довгостроковий або короткостроковий період виробництва і постачання, управління запасами, стратегії розподілу готової продукції і розширення кола потенціальних клієнтів, розглядаються на тактичному рівні і приймаються на кожний квартал або рік. Рішення, що приймаються на кожен день - наприклад, планування транспорту, складання розкладу виробництва, встановлення термінів поставок продукції клієнтам тощо - це рішення оперативного рівня.

Сегментація ринку в залежності від вимог до якості послуг, індивідуалізація логістичної мережі, збір інформації з ринків і розробка відповідних планів, індивідуалізація необхідних товарів клієнтам, вибір стратегічних ресурсів для постачання, розвиток технологічної стратегії на рівні всього ланцюга постачання, прийняття показників рівня якості щодо всього ланцюга поставок ось ті головні принципи, які забезпечують високу ефективність в управлінні ланцюгами постачання [4]:

Погані наслідки з'являються, якщо реалізувати напрактиці всі ці принципи не вдається. Також проблеми під час управління ланцюгами поставок виникають: за відсутності належної інфраструктури, що могла б забезпечити фрункціональну діяльність ланцюга постачання; без наявності раціональних ініціатив; за надмірних витратах ресурсів ічасу за умов обмеженості координації в роботі управлінських структур ланцюгом постачання; за неякісної реалізації плану щодо реорганізації ланцюга постачання.

Як свідчить досвід діяльності європейських та американських логістичних компаній, за наявності багатьох показників оцінки ефективності управління ланцюгом поставок, достатнім $є$ використання двох з них рівня ризику щодо своєчасності поставки продукції замовнику та рівня надійності роботи ланцюга.

У сучасних нестабільних умовах господарювання, надійність $€$ одним із основних сучасних логістичних пріоритетів, що закладені в загальну стратегію діяльності логістичних компаній та виступає в якості комплексного показника ефективної діяльності логістичних систем і ланцюгів поставок. Такі показники надійності, як своєчасність поставки (відсоток замовлень, що виконані в зазначений термін) і повнота поставки (відсоток замовлень, що виконані в повному обсязі) доцільно використовувати під час аналізу ланцюга поставок по всій його довжині - від початку і до кінця.

Європейські та американські компанії оцінюють надійність ланцюга поставок у залежності від фракторів ризику [4]: затримка поставки (компанія Tesco UK), точність комплектації замовлення (компанія Tesco UK) час виконання замовлення (компанія Vision Express UK), кількість дефектних деталей в замовленні (компанія Nissan UK), час доставки (Королівська пошта UK) повнота поставки в зазначений термін (компанія Siemens EMS).

Проблеми управління ланцюгами поставок у сучасній літературі розглядаються в розрізі різних моделей, і при їх розгляді достатньо уваги приділяється мо- 
делі SCOR. Модель SCOR (Supply Chain Operation Reference Model - Довідкова модель операцій ланцюга поставок), що запропонована The Supply Chain Council (США) аналізує сьогоднішній стан компанії і її цілі, визначає основні кількісні показники і порівнює їх з даними бенчмаркінга (тобто із кращими показниками в даній галузі або на цьому ринку). Для характеристики роботи ланцюгів поставок і їх учасників, SCOR розробила набір показників. Для бенчмаркінга застосовуються створений банк інформації про особисті досягнення в соері логістики. Для опису бізнес-процедур учасників ланцюгів поставок, модель SCOR містить уніфікований термінологічний апарат, а типові логістичні процеси і показники ефективності ланцюгів постачання допомагають в проведенні реінжинірингу технологій поставок.

Використання моделі SCOR, за даними Ради по ланцюгах поставок (The Supply Chfin Counsil - SCC), надає фірмам і компаніям можливість [4]: зменшити логістичні витрати в межах ланцюга; прискорити товарообіг; зменшити запаси ресурсів (наприклад, Co. Siemens Medical, застосувавши SCOR, скоротила строк доставки продукції майже вдвічі і приблизно на 40 \% зменшила обсяг запасів); знизити повернення обсягів продукції постачальникам.

Модель SCOR спрямована на оптимізацію логістичних функцій надійності, оперативності поставок, ефективності управління активами, гнучкості витрат і включає: планування і управління попитом / поставками, постачання із сформованого обсягу запасів; розробку і виробництво продукції під замовлення і під запас; управління замовленнями, складуванням і доставкою продукції; повернення при необхідності сировини, матеріалів і готової продукції [4]. Ця модель може стати галузевим логістичним стандартом, а її додатковою перевагою $\epsilon$ те, що вона акцентує на основних показниках у ланцюгах поставок, які потрібно контролювати.

Попри те, що провідні компанії приділяють велику увагу плануванню своїх ланцюгів постачань, наявні свідчення та дослідження сигналізують про те, що навіть у них ланцюги поставок цілеспрямовано не проектувалися, в тойчас, як грамотно спроєктовані та сфрормовані ланцюги постачань визначають динаміку товарно-матеріальних, інфоормаційних, фрінансових і інших потоків у процесі відтворення, реалізують функції обміну та розподілу. Отже, варто розуміти, що ефективне управління ланцюгами постачань ї̈х організація якісно впливають на темпи, а такожпропорції економічного розвитку національної економіки України загалом.

Ефективне управління ланцюгами поставок може принести компаніям багато зисків, але у багатьох випадках, вони навіть не знають про всі еквівалентні варіанти побудови ланцюгів, через що кінцеві рішення часом виявляються далеко не досконалими. Узгодження стратегії ланцюгів постачання із загальною стратегією бізнес-структури, розгляд різних варіантів конфігурації ланцюжків постачань i здійснення структурних змін з метою їх коригування, можуть сприяти підвищенню рентабельності. Переглядаються колишні ланцюги поставок також у зв'язку з змінами у зовнішньому середовищі (зміни в запитах кінцевих користувачів, ринках продукції та товарних серіях, економіки в цілому, загальної конкурентної ситуації, стимулюючих діях уряду), що часто вимагає перегляду угод між партнерами.

Основна мета процесу планування логістичного ланцюга полягає в тому, щоб забезпечити безперебійне ви- робництво тапрогнозування попиту, розробити досконалі виробничі плани, оптимізувати поповнення запасів, і створювати можливості для моніторингу товарних потоків на всій протяжності логістичного ланцюга, що дозволить здійснити своєчасну доставку товарів зазначеної кількості у вказане місце. Всі коригувальні дії при змінах у структурі споживчого попиту потрібно здійснювати вчасно.

Ланцюг постачання не $є$ прямолінійний, його формують величезна кількість ланок різної потужності. Тому якісь з ланок, що мають найменшу потужність, обмежують загальну пропускну здатність ланцюга і стають вузьким місцем ланцюга постачань [5, с. 228].

Отже, основними характеристиками ЛП є довжина, ширина тапотужність [6, с.74]: довжина ланцюга поставок залежить від кількості постачальників, споживачів і посередників, через яких матеріали проходять від початку виробництва (добування) до місця призначення - тобто до кінцевого споживача; ширина ланцюга поставок - це кількість паралельних маршрутів, за якими може переміщатися продукція; потужність ланцюгапоставок - це максимальний обсяг матеріального потоку, що може пройти через ланцюг за визначений проміжок часу. Загальна потужність ланцюга поставок визначається частиною (фррагментом) з найнижчою пропускною можливістю, тобто найнижчою потужністю, що визначає "вузьке місце" ланцюга поставок іє визначальним в його діяльності. Таким чином, одним зі способів підвищення потужності ланцюга поставок $€$ підвищення потужності в його "вузькому місці".

Підвищення ефективності ланцюга постачань передбачає використання стратегії формування союзів з постачальниками та замовниками, метою якої $є$ спільна праця членів на досягнення результату та довгострокове отримання зиску від такої кооперації. Спонукаючими фракторами до використання цієї стратегії є прагнення до кращого обслуговування споживачів, зниження витрат, намагання уникнення ризиків при інвестуванні, запозичення досвіду у партнерів. Найбільш часто партнерства створюються між транспортними компаніями. До інших сфрер співробітництва відносяться складування, послуги в сорері імпорту / експорту, обробка інформації [7, с. 14].

Потужним стимулом та інструментом розвитку нових концепцій управління ланцюгами постачання стали інфоормаційні технології. Інформаційні технології стали також основою забезпечення й підвищення ефрективності ланцюгів постачання, бо з'явилася можливість реалізувати найважливіші ідеї управління ланцюгами постачання, а саме: інформаційну координацію та синхронізацію попиту і постачання. В сьогоднішніх умовах управління ланцюгами постачання розвивається стрімко і набуває величезного значення для промислових, торговельних і логістичних підприємств, а інтеграція та координація суттєво відрізняє управління ланцюгами від традиційних концепцій міжфірмового кооперування. Враховуючи інтегрований підхід до формування всіх ділянок і елементів процесу створення вартості продукту, практика управління ланцюгами поставок довела ефективність побудови та аналізу бізнесу. Врахування тільки витрат і прибутку підприємства без обліку впливу на них міжорганізаційних зв'язків з постачальниками та відносин із клієнтами відображає не в повній мірі картину ефективності господарювання підприємства. Принаймні існує п'ять галузевих напрямів, а саме: автомобілебудування, авіабудуван- 
ня, електротехніка, оптова й роздрібна торгівля, споживчі й фармацевтичні товари, де управління ланцюгами постачання $€$ одним з головних напрямів підвищення ефективності фрункціонування бізнесу.

Важливо зазначити, що в управлінні ланцюгами поставок перейдено від простої інформаційної координації та операційної кооперації до інтегрованої взаємодії в ланцюгах постачання, що змушує розглядати процес управління ланцюгами постачання як концепцію управління бізнесом.

В Україні, так само як і за кордоном, процес управління ланцюгами постачання розглядається як бізнес-концепція, як середовище інформаційної взаємодії підприємств, як самостійний науковий напрям. Тобто процес управління ланцюгами постачання розглядається з трьох позицій, і найбільше переплітаються між собою інфрормаційні технології та бізнес-процеси. Вельми важливим $€$ розуміння взаємозв'язків між бізнес-концепціями, інформаційними технологіями та моделюванням ланцюгів поставок, бо оптимізація цих взаємозв'язків та ефективне моделювання ланцюгів поставок сприяють досягненню конкурентних переваг бізнесу та підвищенню ефективності управління ланцюгами постачання.

\section{ВИСНОВКИ ТА ПЕРСПЕКТИВИ ПОАААЬШИХ РОЗВІАОК}

Отже, під час управління ланцюгом постачань виникає завдання мінімізації логістичних витрат та досягнення конкурентних переваг, водночас необхідно домогтися об'єднання ринку, виробничого процесу, закупівель та збуту, забезпечивши найвищий рівень обслуговування клієнтів. Нині всі учасники ланцюгів постачання у більшій мірі розуміють важливість не тільки внутрішнього симбіозу потокових процесів, але також і необхідність налагодження тісних взаємозв'язків між постачальниками, підприємством і клієнтами, з метою налагодження оптимального процесу координування операцій між ними та досягнення конкурентних переваг.

За останній час підходи до використання концепцій управління логістично-транспортними системами, так само, як і до логістичного управління економікою загалом, зазнали суттєвих змін, перетворивши логістику, сореру виробництва та доставки продукції увисокорозвинуті інноваційні сорери індустрії. З'явились та розвиваються нові фрорми господарських стосунків, які виникли між виробниками, постачальниками та споживачами продукції, активно впроваджуються та використовуються спільні програми управління процесами постачань ресурсів на основі новітніх інфрормаційних технологій та різноманітних форм партнерської співпраці. Вдосконалення процесів у ланцюгах постачання та здійснення організаційних змін логістичної системи, потребує ефективної стратегії бізнес-діяльності на конкурентному ринку, яку можна реалізовувати, грунтуючись на чотирьох основних підходах: методиці швидкого аналізу рішення (FAST), бенчмаркінгу процесу, перепроєктуванні процесу, реінжинірингу процесу.

У ланцюгах постачання через партнерство, інтеграцію, кооперацію всіх ланок регіональних логістичних систем - виробничих та інфрраструктурних підприємств, організацій і органів державної влади, можна добитися синергетичних ефектів, при цьому оптимізація управління матеріальними та супровідними потоками в Україні, значною мірою залежатиме від ефективності організації функціонування ланцюгів постачання, які поєднують процеси виробництва, споживання та рециклінгу. Все це вимагає детального опрацювання, вивчення, серйозних часових і фінансових вкладень в управління організаційними змінами в ланцюгах постачання.

Підприємства могли б досягти конкурентних переваг та якісніше, але з нижчими витратами задовольнити потреби споживачів, але науково підтвердженні свідчення сигналізують про те, що навіть у провідних компаніях ланцюги постачання цілеспрямовано не проєктувалися, а формувалися з часом свого роду органічним шляхом, що вимагає подальшого дослідження причин зазначених недоліків.

\section{Література:}

1. Чечет А.М. Сучасні тенденції управління ланцюгами поставок / А.М. Чечет / / Вісник НТУ. - 2012. Вип. 26. - С. 351-354.

2. Колодізєва Т.О. Управління ланцюгами поставок: навчальний посібник / Т.О. Колодізєва. - Харків: ХНЕУ ім. С. Кузнеця, 2016. - 164 с.

3. Гукалюк А.Ф. Удосконалення ланцюгів постачання в умовах трендів міжнародного бізнесу / А.Ф. Гукалюк / / Економічний аналіз. - 2015. - Т. 21. - № 2. - С. 48-54.

4. Особливості управління ланцюгами поставок. Навчальні матеріали онлайн [Електронний ресурс]. Режим доступу: https://pidru4niki.com/72787/logistika/osoblivosti_upravlinnya_lantsyugami_postavok (дата звернення: 21.11 .2020$)$.

5. Денисенко М.П., Левковець П.Р., Михайлова Л.І. та ін. Організація та проектування логістичних систем: підручник / за ред. проф. М.П. Денисенка, профр. П.Р. Левковця, проф. Л.І. Михайлової. - К.: Центр учбової літератури, 2010. - 336 с.

6. Сумець О.М. Логістичні системи і ланцюги поставок: навч. посіб. для студ. ВНЗ / О.М. Сумець, Т.Ю.Бабенкова. 2-ге вид., стер. - Х.: КП "Міська друк.", 2013. - 193 с.

7. Окландер М.А. Логістична система підприємства [Текст]: монографрия / М.А. Окландер. - Одеса: Астропринт, 2014. - 312 c.

\section{References:}

1. Chechet, A.M. (2012), "Current trends in supply chain management", Visnyk NTU, № 26, pp. 351-354.

2. Kolodizieva, T. O. (2016), Upravlinnia lantsiuhamy postavok [Supply chain management], Kharkiv, Ukraine.

3. Hukaliuk, A. F. (2015), "Improving supply chains in the context of international business trends", Ekonomichnyi analiz, vol. 21, № 2, pp. 48-54.

4. Training materials online (2020), "Features of supply chain management", available at:https://pidru4niki.com/ 72787 /logistika/osoblivosti_upravlinnya_lantsyugami_postavok (Accessed 20 November 2020).

5. Denysenko, M. P. Levkovets, P. R. and Mykhailova, L. I. (2010), Orhanizatsiia ta proektuvannia lohistychnykh system [Organization and design of logistics systems], Tsentr uchbovoii literatury, Kyiv, Ukraine.

6. Sumets, O. M. (2013), Lohistychni systemy i lantsiuhy postavok [Logistics systems and supply chains], KP Miska drukarnia, Kharkiv, Ukraine.

7. Oklander, M. A. (2014), Lohistychna systema pidpryiemstva [Logistics system of enterprise], Astroprynt, Odesa, Ukraine. Стаття надійшла до редакиї 29.11.2020 p. 